\title{
Deep Drilling with the ANDRILL Program in Antarctica
}

by David Harwood, Richard Levy, Jim Cowie, Fabio Florindo, Tim Naish, Ross Powell, and Alex Pyne

\section{Introduction}

ANDRILL (ANtarctic geological DRILLing) is a new international, multi-disciplinary drilling program that targets geological records that lie hidden beneath the icy blanket of Antarctica. The primary objective is to investigate Antarctica's role in global environmental change over the past sixty-five million years, at various scales of age resolution, and thereby enhance our understanding of Antarctica's potential response to future global changes. Efforts to understand the influence of Antarctica on global climate change require a fundamental knowledge of how the Antarctic cryosphere (ice sheets, ice shelves, and sea ice) has evolved, not only in recent times but also during earlier geological periods when global temperature and atmospheric $\mathrm{CO}_{2}$ levels were similar to what might be reached by the end of this century. ANDRILL's integrated science approach will use stratigraphic drilling, coring, and multi-proxy core analysis combined with geophysical surveys and numerical modeling to study the Cenozoic history of Antarctic climate and ice sheets, the evolution of polar biota, Antarctic tectonism, and Antarctica's role in the evolution of Earth's ocean-climate system.

The two inaugural ANDRILL projects, McMurdo Ice Shelf Project (MIS) and Southern McMurdo Sound Project (SMS), will be drilled in late 2006 and late 2007, respectively, in the McMurdo Sound Region of the Ross Sea (for science plans, see http://andrill.org), and research on these projects will continue throughout the International Polar Year (IPY, 2007-2008). Funding from Germany, Italy, New Zealand, and the United States supported the development of a new dedicated drilling system and drilling camp for ice-based operations. The anticipated twenty-year lifespan of the drilling rig is expected to enable future drilling in other regions of the Antarctic margin. Future ANDRILL projects will depend on new proposals to national funding agencies. ANDRILL is managed through the McMurdo-ANDRILL Science Implementation Committee (M-ASIC) and the ANDRILL Operations Management Group (AOMG), whose directions areimplemented through the Science Management Office (SMO) at the University of Nebraska-Lincoln and the Project Operator's Office within Antarctica New Zealand, respectively. Ongoing and future community involvement, proposal development, and site characterization are encouraged, facilitated, and coordinated by the ANDRILL Science Committee (ASC) and the SMO.

\section{The Drilling System}

The newly built, state-of-the-art ANDRILL drilling system is based on technology proven during the Cape Roberts Project (1995-2000) and has the capability to recover soft sediment and rock strata from more than $1000 \mathrm{~m}$ below the seafloor in $1000 \mathrm{~m}$ of water (Fig. 1). Its narrow-kerf, highspeed, diamond-coring system enables high-percentage $(>90 \%)$ core recovery. The ability to use either fast ice or shelf ice as a drilling platform allows sampling from a wide range of marine environments. The design, engineering, construction, and operational expertise are contracted by Antarctica New Zealand from Victoria University of Wellington and Webster Drilling of New Zealand. The rig underwent testing in Canterbury, New Zealand in late 2005 (Fig. 2) before it was shipped to Antarctica and reassembled near Scott Base in early 2006 (Fig. 3).

The ANDRILL drilling system is based around a miningtype drilling rig constructed by UDR in Brisbane, Australia, but it has been customized for ANDRILL scientific requirements and for Antarctic conditions. Customization includes (1) reconfiguration of the main winch for a double line pull to deploy sea-riser casing, which weighs up to thiry tons; (2)

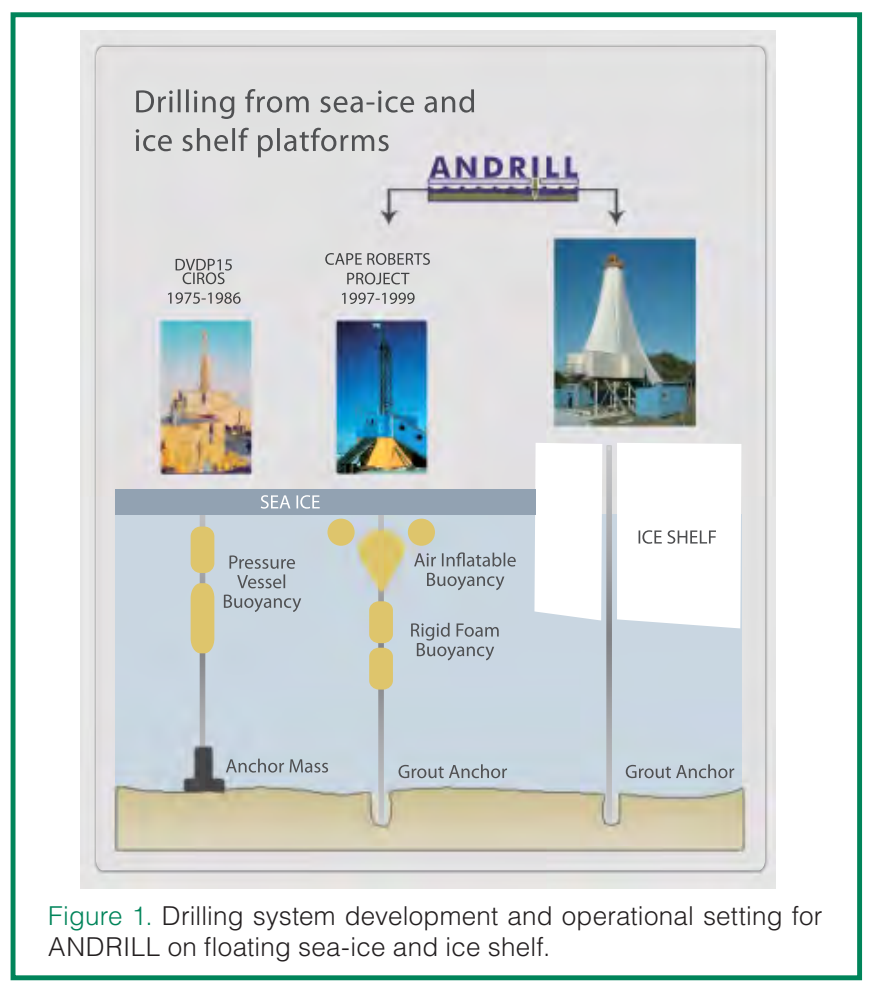




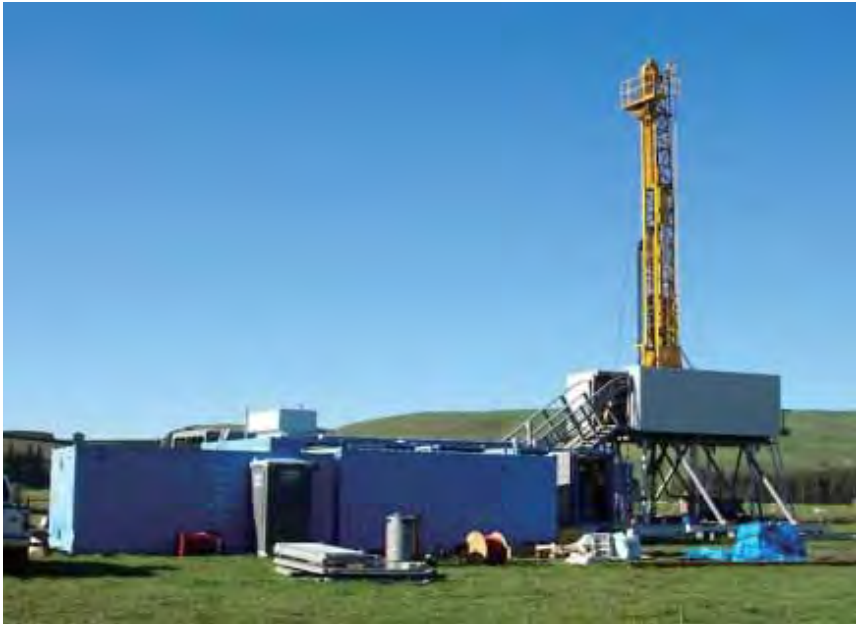

Figure 2. Testing ANDRILL rig in Canterbury, New Zealand (October 2005) before shipping south to Antarctica.

heave compensation to allow for up to 1.5 meters of vertical tidal movement of the ice shelf or sea-ice platform, (3) enclosure to provide a warm environment for workers and equipment on the drill floor, and (4) separation of the rig hydraulic power pack (in an insulated container) and the drill mast and winches to provide the best heated location. The entire system can be broken down into components that can be airlifted or transported on sledges. Some parts of the system, such as the drilling platform and catwalk, have been designed and fabricated to incorporate sledge bases for easy transport across snow and ice (Table 1).

\section{Science Plan}

During the austral summers of 2006 and 2007, ANDRILL will drill from an ice-shelf platform for the MIS Project and a sea-ice platform for the SMS Project in the McMurdo Sound region to obtain new information about the Neogene Antarctic cryosphere and the evolution of Antarctic rift basins. The McMurdo Sound region was selected for the first phase of ANDRILL for scientific and logistical reasons. McMurdo Sound is located at the juncture of several components of the West Antarctic Rift System, including the Victoria Land Basin, Transantarctic Mountains, and Erebus Volcanic Province (Fig. 4). This region is also situated near the confluence of several components of the Antarctic cryosphere, including the East and West Antarctic ice sheets, local alpine glaciers, and sea ice. As proven by Cape Roberts

Table 1. Components of the drilling system include:

drill rig and the drill platform

the catwalk sledge \& rod ramp, providing staging area for the sea riser and drill pipe

the drill fluids (mud) system, providing a fluid for cooling the drill bit and lifting drill cuttings from the base of the hole

the cementing system, which can supply cement to anchor the sea riser to the sea floor, case or plug off the hole

the hydraulic power system, which supplies the drill rig, and two electrical generators

the hot water drilling system, which will keep an open hole around the sea riser pipe drilling, proximity to the Transantarctic Mountains combined with ample accommodation space from tectonic subsidence of the Victoria Land Basin gives the region excellent potential to produce high-quality, time-continuous paleoenvironmental records, during times of both large and small Antarctic ice sheets. In some areas of McMurdo Sound, Neogene volcanism has produced flexural-moat basins superposed on the Victoria Land rift basin. The flexural moats provide an ideal setting for sediment accumulation and a means of developing a high-resolution chronology from volcanic detritus. The MIS and SMS drilling sites are based on geophysical and seismic surveys combined with knowledge gained at other nearby drilling sites. Both study areas are located to maximize the potential recovery of new stratigraphic records.

The scientific objectives of these two inaugural ANDRILL projects are as follows: (a) to document the initial onset and subsequent history of sea-ice presence or absence, (b) to document the evolution and demise of Neogene terrestrial vegetation, (c) to establish a local Late Neogene sea-level record, (d) to test whether stable, cold-polar climate conditions persisted for the last 15 M.y., (e) to construct a composite history of glacial and interglacial events across a coastal to deep basin transect, (f) to provide chronostratigraphic control for the regional seismic framework in the Victoria Land Basin and western Ross Sea, ( $g$ ) to develop a Neogene subsidence and fault history for the Victoria Land Basin, and (h) to feed new paleoclimatic data into ice-sheet and climate models.

The main goal of the McMurdo Ice Shelf Project (MIS) is to determine past ice-shelf responses to climate forcing, including variability at a range of timescales. One borehole in approximately $900 \mathrm{~m}$ water depth will sample a $1200-\mathrm{m}$ thick body of Plio-Pleistocene glaciomarine, terrigenous, volcanic, and biogenic sediment within the Windless Bight region of a flexural moat basin surrounding Ross Island. The MIS Project is led by Co-Chief Scientists Tim Naish and Ross Powell.

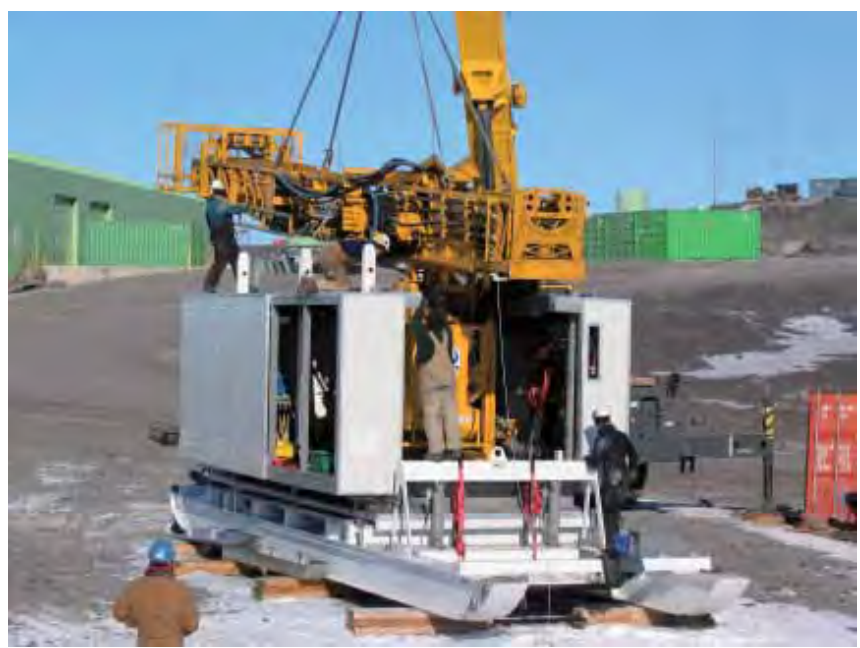

Figure 3. Attaching drilling rig mast to jack-up platform after offload in McMurdo. Assembly of ANDRILL System at ice edge near New Zealand's Scott Base. 

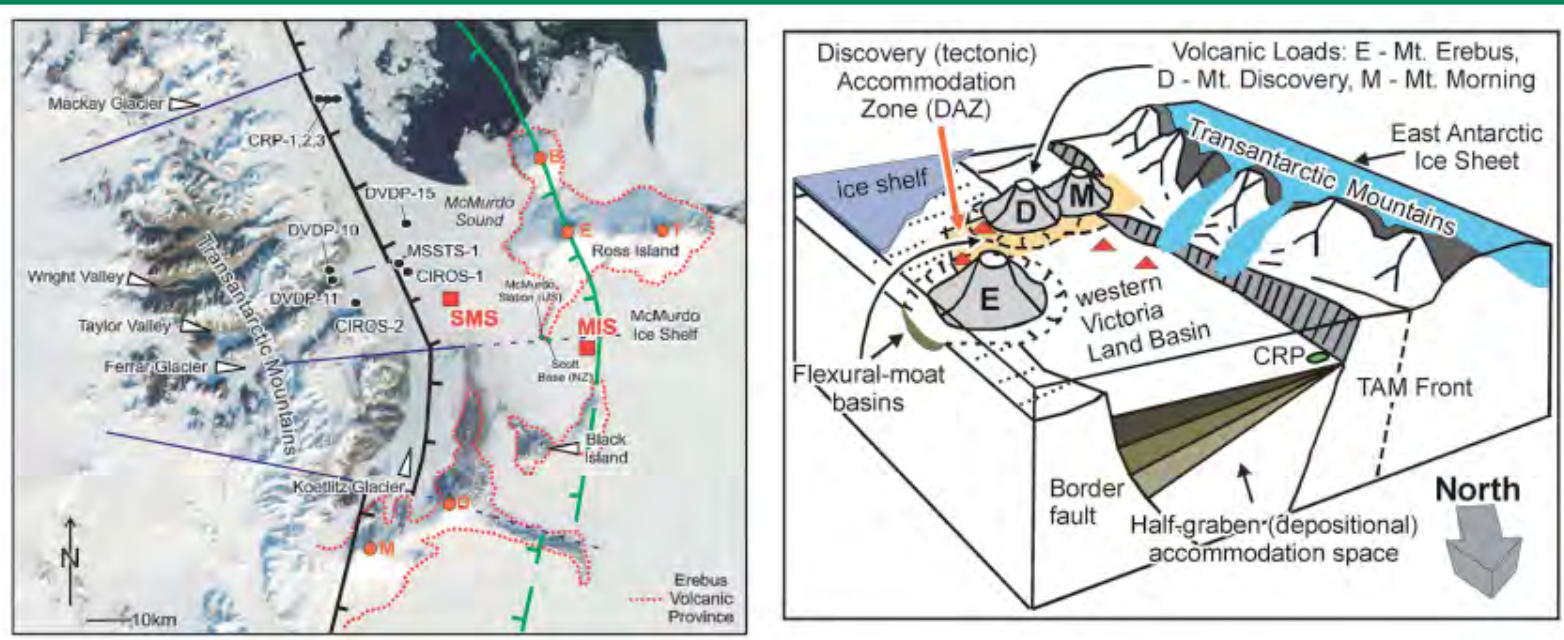

Figure 4. Left: McMurdo Ice Shelf (MIS) and Southern McMurdo Sound (SMS) Projects (red squares) are scheduled for drilling during 2006 and 2007 austral summers, respectively. Also shown are locations of previous stratigraphic bore holes (DVDP, CIROS, MSSTS, and CRP) in McMurdo Sound region. Right: Schematic stratigraphic and structural cartoon of Victoria Land Basin shows development of accommodation space within half graben. Neogene volcanoes of Erebus Volcanic Province have progressively depressed crust forming flexural-moat basins that trap an expanded Neogene sediment history.

The main goal of the Southern McMurdo Sound Project (SMS) is to establish the history of Neogene Antarctic icesheet variation and longer-term climate evolution. One borehole of more than $1000 \mathrm{~m}$ depth below seafloor in $530 \mathrm{~m}$ water depth will sample a sequence of strata identified on seismic lines and inferred to represent a middle Miocene to upper Miocene sequence of seismic units that expand basinward and are overlain disconformably by Pliocene and Pleistocene strata. This borehole will penetrate strata that lie stratigraphically above the lower Miocene section recovered at the top of the sequence drilled by the Cape Roberts Project. The SMS Project is led by Co-ChiefScientists David Harwood and Fabio Florindo.

The selected drilling sites lie close to existing Antarctic logistical centers, including McMurdo Station (U.S.) and Scott Base (New Zealand), thus minimizing the logistical difficulties associated with operating a new drilling system in an extreme environment. The Crary Science and Engineering Center (CSEC or Crary Lab) at McMurdo Station is a state-of-the-art science facility in which most of the on-ice scientific analyses will occur, and access to Crary Lab allows ANDRILL to involve a full scientific team to achieve comprehensive on-ice core characterization and analysis. Other research will be conducted during drilling and at the home institutions of the science team members. Approximately one hundred scientists, students, educators, technical assistants, and drilling team members will be involved in each project, on and off the ice. The ARISE Program (ANDRILL Research Immersion for Science Educators) will bring six educators to Antarctica as members of the science team for both projects to develop further a set of diverse and effective education and outreach materials with a polar content for the IPY and beyond.

\section{Acknowledgements}

Submitted by David Harwood and Richard Levy on behalf of members of the M-ASIC and AOMG committees, the staff of the ANDRILL Project Operator within Antarctica New Zealand, the staff of the Science Management Office at the University of Nebraska-Lincoln, and the staff of the Antarctic Research Centre of Victoria University of Wellington. Members of these ANDRILL bodies are identified at the new Web site for ANDRILL (http://andrill.org), which can be visited for more information. The SMO is supported by a grant from the U.S. National Science Foundation.

\section{Authors}

David Harwood and Richard Levy, ANDRILL Science Management Office, University of Nebraska-Lincoln, 126 Bessey Hall, Lincoln, Neb. 68588-0341, U.S.A. e-mail: dharwood1@unl.edu and rlevy2@unl.edu.

Jim Cowie, Antarctica New Zealand, Administration Building, International Antarctic Centre, 38 Orchard Road, Private Bag 4745, Christchurch, New Zealand.

Fabio Florindo, Istituto Nazionale di Geofisica e Vulcanologia, Via di Vigna Murata, 606, 00143 Rome, Italy.

Tim Naish, GNS Science, 1 Fairway Drive, PO Box 30-368, Lower Hutt, New Zealand.

Ross Powell, Department of Geology and Environmental Geosciences, Northern Illinois University, 312 Davis Hall, Normal Road, DeKalb, Ill. 60115-2854, U.S.A.

Alex Pyne, Antarctic Research Centre, School of Earth Sciences, Victoria University of Wellington, PO Box 600, Wellington, New Zealand.

\section{Related Web Links}

http://andrill.org

http://www.ipy.org

\section{Figure Credits}

Fig. 2: photograph by Alex Pyne.

Fig. 3: photograph by Tim Naish. 